\title{
OPTIMASI AKTIVITAS BAKTERIOSIN YANG DIHASILKAN OLEH Lactobacillus casei DARI SOTONG KERING
}

\author{
Winny Andarilla ${ }^{1}$, Rafika Sari ${ }^{2}$, Pratiwi Apridamayanti ${ }^{3}$ \\ 1,2,3 Program Studi Farmasi, Fakultas Kedokteran, Universitas Tanjungpura \\ J1. Prof. Dr. H. Hadari Nawawi Pontianak 78124 \\ ${ }^{1}$ e-mail: andarillawinny@gmail.com
}

\begin{abstract}
Abstrak
Bakteriosin adalah senyawa protein antimikroba yang dihasilkan oleh bakteri asam laktat (BAL). BAL yang dapat memproduksi bakteriosin dapat ditemukan salah satunya dari sotong kering yang merupakan produk makanan awetan di Kalimantan Barat terbuat dari sotong yang diasinkan dan dikeringkan. Isolat unggulan BAL yang telah diidentifikasi di dalam sotong kering adalah Lactobacillus casei. Lactobacillus casei yang ditemukan perlu dioptimasi lebih lanjut aktivitasnya sebagai agen bakteriosin. Bakteriosin dikonfirmasi dahulu menggunakan enzim proteolitik. Optimasi aktivitas bakteriosin meliputi pengaruh $\mathrm{pH}$, pemanasan, serta penentuan spektrum antimikroba. Uji aktivitas antimikroba menggunakan metode difusi cakram dan parameter pengamatan ditunjukkan dengan adanya zona bening di sekeliling cakram. Hasil penelitian menunjukkan bahwa bakteriosin yang dihasilkan oleh Lactobacillus casei dari sotong kering memiliki aktivitas antibakteri terhadap Escherichia coli dan Staphylococcus aureus. Aktivitas bakteriosin hilang dengan penambahan enzim tripsin, aktivitas berkurang dengan penambahan enzim katalase, dan aktivitas stabil pada rentang $\mathrm{pH}$ 2-6 serta pada pemanasan hingga suhu $40^{\circ} \mathrm{C}$ selama 30 menit.
\end{abstract}

Kata Kunci: Bakteriosin, bakteri asam laktat, sotong kering

\begin{abstract}
Bacteriocins are complex of antimicrobial proteins, produced by the lactic acid bacteria ( $L A B)$. LAB can produce bacteriocin can be found by one of dried cuttlefish which was a preserved food product in West-Borneo made of salted and dried cuttlefish. LAB isolate have been identified in dried cuttlefish is Lactobacillus casei. Lactobacillus casei in dried cuttlefish should be optimized its activity as bacteriocin agent. The bacteriocin was confirmed formerly using a proteolytic enzyme. The optimum range of bacteriocin activity included $\mathrm{pH}$, heat treatments, and antimicrobial spectrum. The antimicrobial activity was testing used disc diffusion method and observation parameters indicated by a clear zone around the disc. The results showed that bacteriocin produced by the Lactobacillus casei of the dried cuttlefish has an anti-bacterial activity towards Escherichia coli and Staphylococcus aureus. The activity of bacteriocin was lost to the addition of trypsin enzyme, the activity was decreasing with the addition of catalase enzyme, and the stable activity at the $\mathrm{pH}$ of 2-6 as well as to warm up to $40^{\circ} \mathrm{C}$ for 30 minutes.
\end{abstract}

Keywords:Bacteriocin, lactic acid bacteria, Lactobacillus casei, dried cuttlefish

\section{PENDAHULUAN}

Bahan pengawet sering ditambahkan pada makanan agar tidak mudah dirusak oleh mikroba dan lebih tahan lama. Bahan pengawet dapat 
memperpanjang waktu penyimpanan makanan dengan cara menghambat pertumbuhan bakteri pembusuk sehingga dapat meningkatkan mutu makanan. Bahan pengawet yang sering digunakan biasanya berupa senyawa-senyawa kimia. Senyawa kimia tersebut tentunya dapat memengaruhi tubuh baik secara langsung maupun ketika terakumulasi. Penggunaan pengawet dalam takaran yang tidak tepat ataupun terlalu sering dapat bersifat toksik dan membahayakan tubuh. Pengawet benzoat yang digunakan dalam jangka panjang dapat berefek negatif bagi tubuh, salah satunya yaitu kerusakan pada ginjal (Hilda, 2015). Meningkatnya kesadaran akan pentingnya kesehatan menyebabkan dibutuhkannya suatu bahan pengawet alami yang lebih aman dan tidak membahayakan kesehatan.

Bakteriosin merupakan salah satu senyawa alami yang memiliki potensi digunakan sebagai bahan pengawet. Bakteriosin dapat digunakan sebagai antibiotik alami karena mampu menghambat bakteri Gram positif dan bakteri Gram negatif. Selain itu bakteriosin juga dapat dimanfaatkan sebagai biopreservatif makanan karena memiliki beberapa keuntungan, yaitu tidak toksik dan mudah mengalami biodegradasi karena bakteriosin adalah senyawa protein yang tidak membahayakan mikroflora usus, mudah dicerna oleh enzim-enzim dalam saluran pencernaan, dan aman bagi lingkungan (Suganya et al., 2015).

Bakteriosin dapat dihasilkan oleh beberapa galur Bakteri Asam Laktat (BAL). BAL yang dapat memproduksi bakteriosin dapat ditemukan dari produk makanan fermentasi dan produk makanan olahan lainnya. Lactocin 705 merupakan bakteriosin yang diperoleh dari Lactobacillus casei CRL 705, dilaporkan aktif terhadap bakteri patogen yang terdapat dalam makanan dan telah diaplikasikan sebagai agen biopreservatif pada daging fermentasi (Palacious et al., 1999). Berdasarkan penelitian sebelumnya, BAL telah diisolasi dan diidentifikasi dari sotong kering. Sotong kering merupakan produk makanan awetan di Kalimantan Barat yang terbuat dari sotong yang diasinkan dan dikeringkan. Isolat unggulan BAL yang telah diidentifikasi di dalam sotong kering adalah Lactobacillus casei (Yurinda, 2016).

Lactobacillus casei yang ditemukan pada sotong kering perlu dioptimasi lebih lanjut aktivitasnya sebagai agen bakteriosin. Optimasi pada penelitian ini 
dilakukan untuk mengetahui kondisi optimum agar aktivitas antibakteri bakteriosin tetap maksimal. Adapun manfaat penelitian ini yaitu memberikan informasi tentang kondisi optimum bakteriosin yang dihasilkan oleh Lactobacillus casei dari sotong kering terhadap aktivitasnya sebagai pertimbangan dalam pengembangan agen biopreservatif serta menambah wawasan dan pengetahuan tentang bakteriosin sebagai agen pengawet yang aman bagi tubuh.

\section{METODE}

\section{Alat dan Bahan}

Cawan petri (Iwaki pyrex), jarum Ose, kaca objek, tabung reaksi, tabung erlemeyer (Iwaki pyrex), gelas beaker (Iwaki pyrex), autoklaf, mikroskop, inkubator, Laminar Air Flow (LAF), bunsen, lemari pendingin, mikro sentrifugasi, filter bakteri, dan jangka sorong.

Isolat Lactobacillus casei dari sotong kering, media De Man Rogosa and Sharpe (MRS) agar, media De Man Rogosa and Sharpe (MRS) broth, akuades, kristal violet, iodium, etanol 95\%, safranin, dapar fosfat, $\mathrm{NaOH}, \mathrm{HCl}$, dan media Mueller Hinton Agar (MHA).

\section{Prosedur Penelitian}

\section{Peremajaan BAL}

Kultur bakteri berumur 48 jam yang telah diisolasi dari sotong kering pada penelitian sebelumnya ditumbuhkan pada media De Man Rogosa Sharp Agar (MRSA) dengan metode striking dan diinkubasi pada suhu $32^{\circ} \mathrm{C}$ selama 48 jam, kemudian diambil satu koloni dan dimasukkan ke De Man Rogosa Sharp Broth (MRSB). Kultur kemudian diinkubasi pada suhu $32^{\circ} \mathrm{C}$ selama 48 jam (Pelczar et $a l, 2005)$.

\section{Konfirmasi BAL}

Bakteri diperiksa dengan pewarnaan Gram. Pewarnaan Gram dilakukan dengan cara satu tetes kristal violet ditambahkan pada preparat yang telah diolesi isolat BAL yang berumur 24 jam. Preparat dibiarkan selama 1 menit dan dicuci dengan akuades. Sebanyak 1 tetes iodium ditambahkan ke dalam preparat, dibiarkan selama 2 menit dan dibilas dengan akuades. Preparat dicuci ulang 
menggunakan etanol 95\% dan dibilas pada air mengalir. Isolat BAL ditambahkan safranin, dibilas pada air yang mengalir (Radji, 2010).

\section{Pengambilan Bakteriosin}

Kultur Lactobacillus casei diinokulasikan ke MRS cair 5,0 mL kemudian divortex hingga homogen, dan setelah itu diinkubasi pada suhu $32^{\circ} \mathrm{C}$ selama 48 jam. Kultur cair disentrifugasi dengan kecepatan $10000 \mathrm{rpm}$ pada suhu $4^{\circ} \mathrm{C}$ selama 15 menit. Filtrat dinetralkan hingga $\mathrm{pH}$ 7,0 menggunakan $\mathrm{pH}$ meter dengan menambahkan larutan $\mathrm{NaOH} 1 \mathrm{~N}$. Filtrat disterilkan dengan filter bakteri berdiameter 0,22 $\mu \mathrm{m}$ ke dalam tabung steril untuk memperoleh supernatan antibakteri (Usmiati et al., 2007).

\section{Uji Aktivitas Bakteriosin terhadap E. coli dan S. aureus}

Uji aktivitas antibakteri terhadap bakteri indikator menggunakan metode difusi agar. Sebanyak $20 \mu \mathrm{L}$ supernatan antibakteri diteteskan pada kertas cakram steril berdiameter $6 \mathrm{~mm}$. Kertas cakram diletakkan di atas media MHA yang mengandung bakteri uji (E.coli dan S.aureus). Diameter zona bening yang dihasilkan di sekitar kertas cakram diukur dengan menggunakan jangka sorong setelah diinkubasi selama 24 jam suhu $37^{\circ} \mathrm{C}$ (Sidabutar et al., 2015).

\section{Uji Aktivitas Bakteriosin terhadap Enzim Proteolitik}

Sebanyak $250 \mu \mathrm{L}$ supernatan bakteriosin dicampur dengan $750 \mu \mathrm{L}$ enzim konsentrasi $1 \mathrm{mg} / \mathrm{mL}$ dilarutkan dalam dapar pospat $\mathrm{pH}$ 7,6 untuk enzim tripsin dan dapar pospat $\mathrm{pH} 7$ untuk enzim katalase kemudian diinkubasi selama 5 jam pada suhu $25^{\circ} \mathrm{C}$. Filtrat disterilkan dengan filter Millipore berdiameter 0,22 $\mu \mathrm{m}$ ke dalam tabung steril. Sebanyak $20 \mu \mathrm{L}$ supernatan antibakteri diteteskan pada kertas cakram steril berdiameter $6 \mathrm{~mm}$. Kertas cakram diletakkan diatas media MHA yang mengandung bakteri uji (E. coli dan S. aureus). Diameter zona bening yang dihasilkan di sekitar kertas cakram diukur dengan menggunakan jangka sorong setelah diinkubasi selama 24 jam suhu $37^{\circ} \mathrm{C}$ (Sari et al., 2011).

\section{Pengaruh pH terhadap Aktivitas Bakteriosin}

Sebanyak $5 \mathrm{ml}$ larutan bakteriosin kasar pada tabung yang berbeda, masing-masing diatur $\mathrm{pH}$ nya pada $\mathrm{pH}$ 2, 4, 6, 8, dan 10 menggunakan larutan $\mathrm{NaOH}$ atau $\mathrm{HCl}$. Setelah diinkubasi selama 4 jam pada suhu kamar, selanjutnya 
aktivitas bakteriosin diuji menggunakan metode difusi agar (Kusmarwati et al., 2014).

\section{Pengaruh Pemanasan terhadap Aktivitas Bakteriosin}

Sebanyak $5 \mathrm{ml}$ supernatan bakteriosin masing-masing dipanaskan pada suhu $40,60,80$, dan $100^{\circ} \mathrm{C}$ selama 30 menit di waterbath thermostatic dan $121^{\circ} \mathrm{C}$ selama 15 menit di autoklaf (Saad et al., 2015). Aktivitas bakteriosin kemudian diuji dengan metode difusi agar menggunakan bakteri uji E. coli dan S. aureus.

\section{HASIL DAN PEMBAHASAN}

Sampel yang digunakan berupa isolat Lactobacillus casei yang diperoleh dari sotong kering. Pada penelitian ini Lactobacillus casei diremajakan terlebih dahulu bertujuan untuk mengaktifkan kembali bakteri. Hal ini dikarenakan bakteri tersebut disimpan dalam lemari pendingin sehingga menjadi inaktif. Peremajaan dilakukan dengan cara mengambil 1 koloni tunggal kemudian diinokulasikan pada media deMan Rogose Sharp Agar (MRSA) yang baru. Inkubasi dilakukan pada inkubator pada suhu $32^{\circ} \mathrm{C}$ selama 48 jam. Hasil peremajaan isolat Lactobacillus casei yang diperoleh dari sotong kering setelah diinkubasi pada suhu $32^{\circ} \mathrm{C}$ selama 48 jam yaitu terlihat bahwa koloni berwarna putih telah tumbuh di media MRSA. Isolat Lactobacillus casei hasil peremajaan pada MRSA koloni berbentuk halus, bulat, dan berwarna putih. Media MRS merupakan media selektif untuk menumbuhkan Lactobacillus. Media selektif dirancang untuk menekan pertumbuhan bakteri yang tidak diinginkan dan mendukung pertumbuhan bakteri yang diinginkan (Radji, 2010).

Media MRS mengandung pepton, beef extract, yeast extract, dekstrosa, tween 80, ammonium sitrat, magnesium sulfat, mangan sulfat, dipotassium fosfat dan sodium asetat. Pepton dan beef extract sebagai sumber nitrogen dan karbon. Yeast extract menyediakan vitamin B kompleks dan dekstrosa sebagai sumber energi. Tween 80 merupakan surfaktan yang membantu dalam penyerapan nutrisi oleh Lactobacilli. Ammonium sitrat pada $\mathrm{pH}$ rendah menunjang pertumbuhan bakteri asam laktat. Dipotasium fosfat dan sodium asetat merupakan buffer untuk 
menjaga $\mathrm{pH}$ tetap rendah. Magnesium sulfat dan mangan sulfat menyediakan ion penting untuk pertumbuhan dan metabolisme Lactobacilli (De Man et al., 1960).

Konfirmasi BAL merupakan tahapan untuk memastikan bahwa bakteri asam laktat yang dihasilkan pada saat peremajaan bakteri adalah benar merupakan isolat Lactobacillus casei. Konfirmasi BAL dilakukan dengan uji pewarnaan Gram. Hasil pewarnaan Gram menunjukkan bahwa isolat Lactobacillus casei merupakan Gram positif. Hal ini dikarenakan bakteri tersebut dapat mempertahankan warna ungu dari kristal violet pada pencucian dengan alkohol 96\%. Bakteri Gram positif memiliki peptidoglikan yang tebal. Berdasarkan teori Salton pencucian dengan alkohol $96 \%$ pada bakteri Gram positif akan menyebabkan protein pada dinding sel mengalami denaturasi sehingga pori-pori mengecil dan kompleks ungu kristal iodium tetap terperangkap pada dinding sel akibatnya bakteri berwarna ungu (Radji, 2010). Hasil pengamatan bakteri secara mikroskopik terlihat bahwa bakteri berbentuk batang. Hal ini sesuai dengan ciri Lactobacillus casei pada Bergey's yaitu berbentuk batang berantai pendek atau panjang (Breed et al., 1957).

Hasil uji aktivitas bakteriosin yang dihasilkan oleh Lactobacillus casei dari sotong kering disajikan pada Tabel 1 dan Tabel 2. Hasil uji tersebut menunjukkan bahwa bakteriosin memiliki aktivitas antibakteri terhadap bakteri uji yaitu Escherichia coli dan Staphylococcus aureus. Hal ini sesuai dengan penelitian yang telah dilakukan Mohanty et al., (2016) menyatakan bahwa bakteriosin dari Lactobacillus casei (DM 60) yang diisolasi dari yoghurt, menunjukkan aktivitas antimikroba terhadap beberapa bakteri patogen pada makanan yaitu Escherichia coli, Bacillus cereus, dan Staphylococcus aureus. Aktivitas antibakteri bakteriosin yang dihasilkan oleh Lactobacillus casei dari sotong kering lebih sensitif terhadap bakteri Gram positif yaitu Staphylococcus aureus bila dibandingkan dengan bakteri Gram negatif yaitu Escherichia coli. Perbedaan sensitivitas tersebut dapat dikarenakan bakteri Gram negatif memiliki membran luar yang bertindak sebagai barier sehingga bakteri Gram negatif lebih sulit ditembus oleh bakteriosin (Prudencio et al., 2015). 
Tabel 1. Hasil Uji Aktivitas Bakteriosin terhadap E. coli dan S. aureus

\begin{tabular}{llll}
\hline \multirow{1}{*}{ Bakteri Uji } & \multicolumn{3}{c}{ Zona Hambat (mm) } \\
\cline { 2 - 4 } & \multicolumn{1}{c}{ I } & \multicolumn{1}{c}{ II } & \multicolumn{1}{c}{$\mathbf{x} \pm$ SD } \\
\hline Escherichia coli & 8,70 & 8,20 & $8,45 \pm 0,353$ \\
Staphylococcus aureus & 12,25 & 12,20 & $12,225 \pm 0,035$ \\
\hline
\end{tabular}

Tabel 2. Hasil Uji Aktivitas Bakteriosin terhadap Enzim Tripsin dan Katalase

\begin{tabular}{llll}
\hline Bakteri Uji & \multicolumn{3}{l}{ Zona Hambat $(\mathbf{m m})$} \\
\cline { 2 - 4 } & I & II & $\mathbf{x} \pm$ SD \\
\hline Escherichia coli & 7,75 & 7,25 & $7,5 \pm 0,35$ \\
Staphylococcus aureus & 11,60 & 8,15 & $9,875 \pm 2,44$ \\
\hline
\end{tabular}

Berdasarkan hasil penelitian, aktivitas antibakteri bakteriosin yang dihasilkan oleh isolat Lactobacilus casei dari sotong kering hilang dengan penambahan enzim tripsin. Hal ini terlihat dari tidak terbentuknya zona hambat pada bakteri uji. Senyawa yang secara keseluruhan maupun sebagian diinaktivasi oleh beberapa enzim proteolitik mengindikasikan bahwa senyawa tersebut memiliki sifat seperti protein, sehingga hasil pada penelitian ini dapat mengindikasikan bahwa komponen antibakteri pada supernatan kemungkinan adalah protein yaitu bakteriosin (Bromberg et al., 2004).

Aktivitas antibakteri bakteriosin yang dihasilkan oleh isolat Lactobacilus casei dari sotong kering tidak hilang dengan penambahan enzim katalase. Hal ini terlihat dari adanya zona hambat pada bakteri uji, namun zona hambat yang terbentuk lebih kecil bila dibandingkan dengan zona hambat bakteriosin tanpa penambahan enzim. Zona jernih yang terbentuk pada perlakuan enzim katalase membuktikan bahwa zona hambat yang terbentuk bukan disebabkan oleh senyawa peroksida melainkan berasal dari bakteriosin (Sari et al., 2011). Hasil pada penelitian ini sama dengan hasil penelitian Vignolo et al., (1993) yaitu aktivitas senyawa antibakteri dari Lactobacillus casei CRL 705 menghilang pada perlakuan dengan enzim tripsin namun aktivitas tetap ada pada perlakuan dengan enzim katalase sehingga aktivitas antibakteri disimpulkan berasal dari senyawa bakteriosin. 
Uji pengaruh $\mathrm{pH}$ terhadap aktivitas bakteriosin dilakukan untuk mengetahui kemampuan bakteriosin sebagai antibakteri ketika berada pada berbagai $\mathrm{pH}$. Hasil uji pengaruh $\mathrm{pH}$ terhadap aktivitas bakteriosin adalah bakteriosin yang dihasilkan oleh Lactobacillus casei dari sotong kering tahan terhadap suasana asam, karena pengujian pada $\mathrm{pH} 2$ sampai $\mathrm{pH} 6$ aktivitas antibakteri tetap ada, namun pada $\mathrm{pH} 8$ terjadi penurunan aktivitas bakteriosin dan aktivitas bakteriosin hilang pada $\mathrm{pH}$ 10. Hasil penelitian Sunaryanto et al. (2015), yaitu kestabilan aktivitas bakteriosin yang dihasilkan oleh Lactobacillus lactis yaitu pada rentang $\mathrm{pH} 3$ sampai dengan $\mathrm{pH}$, namun pada $\mathrm{pH}$ di atas 7 mengalami penurunan aktivitas. Hasil tersebut hampir sama dengan yang dihasilkan pada penelitian ini bahwa bakteriosin yang dihasilkan stabil pada suasana asam, namun tidak stabil pada $\mathrm{pH}$ basa. Artinya, bakteriosin ini dalam aplikasinya hanya dapat digunakan sebagai pengawet pada produk-produk yang memiliki $\mathrm{pH}$ asam hingga netral.

Uji pengaruh pemanasan terhadap aktivitas bakteriosin dilakukan untuk mengetahui kemampuan bakteriosin sebagai antibakteri ketika berada pada suhu tinggi. Stabilitas bakteriosin terhadap suhu penting apabila bakteriosin tersebut akan digunakan sebagai pengawet makanan. Hal ini dikarenakan dalam proses produksi suatu makanan biasanya melibatkan pemanasan. Apabila bakteriosin tidak tahan pemanasan maka tidak bisa digunakan sebagai pengawet pada produk yang memerlukan pemanasan dalam proses pembuatannya karena dikhawatirkan bakteriosin tersebut mengalami kerusakan sehingga aktivitas antibakterinya menjadi tidak efektif lagi dalam pengawetan makanan. Bakteriosin yang dihasilkan oleh Lactobacillus casei dari sotong kering stabil terhadap pemanasan pada suhu $40^{\circ} \mathrm{C}$ selama 30 menit. Namun aktivitas antibakteri bakteriosin tersebut hilang pada suhu pemanasan 60,80 , dan $100^{\circ} \mathrm{C}$ selama 30 menit ditandai dengan tidak terbentuknya zona hambat saat diuji aktivitasnya pada bakteri Escherichia coli dan Staphylococcus aureus. Zona hambat juga tidak terbentuk pada pemanasan suhu $121^{\circ} \mathrm{C}$ selama 15 menit di autoklaf. 


\section{SIMPULAN}

Bakteriosin yang dihasilkan oleh Lactobacillus casei dari sotong kering memiliki aktivitas antibakteri terhadap Escherichia coli dan Staphylococcus aureus. Aktivitas bakteriosin hilang dengan penambahan enzim tripsin, aktivitas berkurang dengan penambahan enzim katalase, dan aktivitas stabil pada rentang pH 2 - 6 serta pada pemanasan hingga suhu $40^{\circ} \mathrm{C}$ selama 30 menit.

\section{DAFTAR PUSTAKA}

Breed, R.S., Murray, E.G.D., \& Smith, N.R. (1957). Bergeys manual of determinative bacteriology. $7^{\text {th }} \mathrm{Ed}$. USA: The Williams and Wilkins Company.

Bromberg, R.I., Moreno, C.L., Zagagini, R.R., Delboni, \& cde Oliveira, J. (2004). Isolation of bacteriocin-producing lactic acid bacteria from meat and meat products and its spectrum of inhibitory activity. Brazilian Journal of Microbiology, 35(1-2): 137-144.

DeMan, J.C., Rogosa, M., \& Sharpe, M.E. (1960). A medium for the cultivation of Lactobacilli. Journal of Applied Microbiology, 23(1): 130-135.

Hilda, N. (2015). Pengaruh pengawet benzoat terhadap kerusakan ginjal. Jurnal Keluarga Sehat Sejahtera, 13(26): 14-21.

Kusmarwati, A., Arief, F.R., \& Haryati, S. (2014). Eksplorasi bakteriosin dari bakteri asam laktat asal Rusip Bangka dan Kalimantan. Jurnal Pascapanen dan Bioteknologi Kelautan dan Perikanan, 9(1): 29-40.

Mohanty, D., \& Ray, P. (2016). Antimicrobial properties of probiotic Lactobacillus casei (DM 60) against selected pathogens. International Journal of Science, Environment, and Technology, 5(3): 1426-1428.

Palacios J, Vignolo G, Farias ME, Holgado APD, Oliver G, Sesma F. (1999). Purification and amino acid sequence of lactocin 705, a bacteriocin produced by Lactobacillus casei CRL 705. Microbiological Research, 154: 199-204.

Pelczar, M.J., \& Chan, E.C.S. (2005). Dasar-dasar mikrobiologi 1. Jakarta: UI Press.

Prudencio, C.V., Santos, M.T., \& Vanetti, M.C.D. (2015). Strategies for the use of bacteriocins in Gram-negative bacteria: relevance in food microbiology. Journal of Food Science and Technology, 52(9): 5408-5417. 
Radji, M. (2010). Buku ajar mikrobiologi: panduan mahasiswa farmasi dan kedokteran. Jakarta: Penerbit Buku Kedokteran EGC.

Saad, M.A., Abdelsamei, H.M., Ibrahim, E.M.A., Abdou, A.M., \& El Sohaimy, S.A. (2015). Effect of $\mathrm{pH}$, heat treatments and proteinase K enzyme on the activity of Lactobacillus acidophilus bacteriocin. Benha Veterinary Medical Journal, 28(1): 210-215.

Sari, R., Cesilia, A., Maksum, R., \& Amarila, M. (2011). Skrining Bakteriosin dari beberapa galur bakteri asam laktat isolat lokal genus Streptococcus dan Weissella. Jurnal Ilmu Kefarmasian Indonesia, 9(2):116-121.

Sidabutar, A.R., Feliatra, \& Andi, D. (2015). Uji aktivitas antimikroba bakteriosin dari bakteri probiotik yang diisolasi dari udang windu (Penaeus monodonFabricus). Jurnal Online Mahasiswa Bidang Perikanan dan Ilmu Kelautan, 2(2): 1-13.

Suganya, K., Murugan, T., \& Murugan, M. (2013). Isolation and characterization of probiotic lactic acid bacteria from milk and curd samples. International Journal of Pharma and Bio Sciences, 4(1): (B) 317-324.

Sunaryanto, R. \& Tarwadi. (2015). Isolasi dan karakterisasi bakteriosin yang dihasilkan oleh Lactobacillus lactis dari sedimen laut. Jurnal Pascapanen dan Bioteknologi Kelautan dan Perikanan, 10(1):11-18.

Usmiati, S., \& Mawarti, T. (2007). Seleksi dan optimasi proses produksi bakteriosin dari Lactobacillus sp. Jurnal Penelitian Pascapanen Pertanian, 4(1): 27-37.

Vignolo, G.M., Suriani, F., Pesce de Ruiz Holgado, A., \& Oliver, G. (1993). Antibacterial activity of Lactobacillus strains isolated from dry fermented sausages. Journal of Applied Microbiology, 75(4): 344-9.

Yurinda, O.D. (2016). Identifikasi Bakteri Asam Laktat (BAL) Penghasil Bakteriosin dari Sotong Kering yang Memiliki Aktivitas Antibakteri Terhadap Bakteri Patogen (Skripsi). Pontianak: Universitas Tanjungpura. 